TAHKIM, Jurnal Peradaban dan Hukum Islam. Vol.4 No.l (Maret, 202I) | ISSN : 2597-7962

\title{
PERNIKAHAN SIRI DALAM PERSPEKTIF HUKUM ISLAM DAN HUKUM POSITIF
}

\author{
Imam Hafas \\ Magister Ilmu Syari'ah, UIN Sunan Kalijaga Yogyakarta \\ imamhafaz02@gmail.com
}

\begin{abstract}
ABSTRAK
Pernikahan adalah sebuah ikatan lahir bathin antara dua belah pihak yang mempunyai tujuan membentuk keluarga bahagia. Adapun, pernikahan yang berlaku di Indonesia adalah pernikahan yang tercatat dan sah secara hukum Islam maupun hukum positif. Namun, dalam penelitian ini yang menjadi permasalahan adalah pernikahan yang tidak tercatat sebagaimana mestinya peraturan berlaku, yaitu nikah siri yang masih banyak terjadi, seperti nikah siri yang biasa atau nikah siri dalam konteks poligami. Rumusan masalah dalam kajian ini yaitu untuk mengetahui kedudukan nikah siri dalam perspektif hukum Islam dan hukum positif. Jenis kualitatif yang menggunakan metode studi pustaka dan pendekatan secara normatif serta komparatif serta penggunaan sumber data yang meliputi data primer dan sekunder. Studi dokumentasi dan wawancara menjadi tehnik pengumpulan data serta menggunakan deskriptif analisis sebagai analisa data yang diperoleh dalam penelitian ini. Hasil penelitian ini menunjukkan bahwa adanya nikah siri yang terjadi karena adanya biaya pernikahan yang mahal, kendala pada masa studi, serta kurangnya pendidikan dan pemahaman tentang pernikahan, sehingga nikah siri tersebut menjadi marak terjadi dikalangan masyarakat yang ada. Pernikahan siri atau pernikahan tanpa pencatatan baik nikah tunggal maupun karena poligami adalah pernikahan yang tidak sah dihadapan hukum positif.
\end{abstract}

Kata Kunci: Nikah Siri, Hukum Islam, dan Hukum Positif.

\begin{abstract}
Marriage is a physical and spiritual bond between two parties that has the goal of forming a happy family. Meanwhile, the marriage that applies in Indonesia is a marriage that is registered and valid under Islamic law and positive law. However, in this study the problem is that marriages are not recorded as the regulations should apply, namely unregistered marriages that still occur frequently, such as regular siri marriages or unregistered marriages in the context of polygamy. The formulation of the problem in this study is to determine the position of unregistered marriage in the perspective of Islamic law and positive law. This type of qualitative uses literature study methods and normative and comparative approaches and uses data sources that include primary and secondary data. Documentation studies and interviews are data collection techniques and use descriptive analysis as an analysis of the data obtained in this study. The results of this study indicate that the existence of unregistered marriage occurs because of the high cost of marriage, constraints during the study period, as well as a lack of education and understanding of marriage, so that unregistered marriages are prevalent among the
\end{abstract}


TAHKIM, Jurnal Peradaban dan Hukum Islam. Vol.4 No.l (Maret, 202I) | ISSN : 2597-7962

existing society. Unregistered marriage or marriage without the registration of either single marriage or because polygamy is a marriage that is not valid under positive law.

Keywords: Siri marriage, Islamic law, and positive law.

\section{A. PENDAhULUAN}

Pernikahan merupakan sunatullah atas penciptaan manusia yang berpasangpasangan. ${ }^{1}$ Dimana perkawinan yang dimaksud adalah sebuah pertemuan antara dua individu dan dua kepribadian yang berbeda. Pernikahan adalah suatu jalan yang amat mulia untuk mengatur kehidupan rumah tangga serta keturunan dan saling mengenal antara satu dengan yang lain, sehingga akan membuka jalan untuk saling tolongmenolong. ${ }^{2}$ Selain itu, pernikahan merupakan institusi yang sangat penting dalam kehidupan bermasyarakat sebagai sarana awal untuk mewujudkan sebuah tatanan masyarakat dan keluarga sebagai pilar penyokong kehidupan bermasyarakat. ${ }^{3}$ Suatu pernikahan yang dilakukan oleh dua orang (laki-laki dan perempuan) mempunyai beberapa konsekuensi, maka dibuat aturan dan prosedur guna menghindari suatu kemungkinan-kemungkinan negatif yang dapat menimbulkan sebuah kerugian. Dimana di Indonesia, prosedur dan aturan yang dibuat bagi masyarakat Islam adalah pernikahan yang dicatat secara resmi dan dipublikasikan.

Aturan tentang adanya pencatatan nikah baik dalam al-Qur'an maupun al-Sunnah pada mulanya memang tidak diatur secara konkrit dalam syariat Islam. Lain halnya dengan ayat mu'amalat (mudayanah) yang dalam situasi tertentu diperintahkan untuk mencatatkan. Namun, sesuai perkembangan zaman dengan berbagai pertimbangan kemaslahatan, Islam di Indonesia mengatur pencatatan pernikahan melalui perundangundangan dengan tujuan untuk mewujudkan ketertiban pernikahan dalam masyarakat. ${ }^{4}$ Melalui pencatatan pernikahan, suami istri akan memiliki akta nikah sebagai bukti otentik atas perbuatan hukum yang telah mereka lakukan. Apabila terjadi perselisihan atau salah satu pihak tidak bertanggung jawab, maka suami atau istri dapat melakukan upaya hukum guna mempertahankan atau memperoleh hak masing-masing. ${ }^{5}$

\footnotetext{
${ }^{4}$ Ahamd Rofiq, Hukum Islam di Indonesia, cet. ke-3 (Jakarta: Raja Grafindo Persada, 1998), hlm. 107.

${ }^{5}$ Ibid., hlm. 107.
} 2000), hlm. 285.

${ }^{1}$ An-Najm (53): 45. Lihat juga Az-Zariyat (51): 49.

${ }^{2}$ Sulaiman Rasyi, Fiqh Islam, cet. ke-25 (Bandung: CV Sinar Baru, 1992), hlm. 348.

3 Abdul Jalil (ed), Fiqh Rakyat: Pertautan Fiqh dengan Kekuasaan, (Yogyakarta: LKiS, 
Namun pada kenyataannya, tidak semua masyarakat Islam di Indonesia mengikuti prosedur atau aturan pencatatan pernikahan tersebut. Sebagian masyarakat masih melaksanakan praktik nikah yang tidak dicatatkan secara resmi kepada Kantor Urusan Agama (KUA) dan tidak dipublikasikan, atau yang dikenal dengan sebutan nikah siri dan sebagian ada yang menyebutnya nikah agama atau nikah di bawah tangan. ${ }^{6}$ Sementara itu, sampai saat ini sebagian ulama dan masyarakat umumnya juga masih belum memiliki kesamaan rumusan yang menimbulkan perbedaan persepsi terhadap nikah siri. Secara normatif, ada yang menilai bahwa praktik nikah siri itu sah dan dapat menimbulkan hikmah positif serta begitu juga sebaliknya, ada yang menilai tidak sah dan dapat menimbulkan implikasi negatif. Apabila dilihat dari perspektif hukum positif dan norma sosial, nikah siri dianggap sebagai suatu deviasi atau penyimpangan. ${ }^{7}$

Di kalangan masyarakat ada yang berasumsi bahwa istilah "nikah siri" dan "nikah dibawah tangan" tersebut sama artinya. $^{8}$ Maka, terlebih dahulu perlu mengidentifikasikan pengertian kedua istilah tersebut untuk menyamakan persepsi agar tidak terjadi kerancuan istilah yang menyebabkan kesalahpahaman.

Sedangkan Menurut Masjfuk Zuhdi, nikah siri muncul sejak diundangkannya UU No. 1 Tahun 1974 tentang pernikahan pada tanggal 2 Januari 1974 yang berlaku secara efektif tanggal 1 Oktober 1975. Nikah di bawah tangan adalah nikah yang dilakukan tidak menurut undang-undang pernikahan, dan nikah yang dilakukan tidak menurut hukum dianggap nikah liar, sehingga tidak mempunyai akibat hukum berupa pengakuan dan perlindungan hukum. Dan pada dasarnya nikah siri adalah kebalikan dari nikah yang dilakukan menurut hukum, dan nikah menurut hukum adalah yang diatur dalam UndangUndang Pernikahan. ${ }^{9}$

Sedangkan nikah siri perspektif hukum Islam menurut Ibnu Taymiyah apabila laki-laki mengawini perempuan dengan cara musyafalah yaitu nikah siri tanpa wali dan saksi serta merahasiakan pernikahan maka pernikahan itu bathil. Pernikahan tidak sah, kecuali ada wali laki-laki, oleh karena itu jika seorang perempuan mengatakan dirinya sendiri untuk menikah, maka pernikahannya tidak sah menurut pendapat Imam Syafi'i

\footnotetext{
6 Dadi Nurhadi, Nikah Di Bawah Tangan (Praktek Nikah Sirri Mahasiswa Jogja),(Yogyakarta: Saujana, 2003), hlm. 26.

${ }^{7}$ Ibid., hlm. 27-28.

${ }^{8}$ Masjfuk Zuhdi, "Nikah Sirri, dan Status Anaknya menurut Hukum Islam dan Hukum Positif”, dalam Mimbar Hukum, VII, 28, 1996, hlm. 7.

${ }^{9}$ Masjfuk Zuhdi, op.cit., hlm. 10-11.
} 
dan Hambali. ${ }^{10}$ Pernikahan siri merupkan dzawatil akhdan (perempuan-perempuan yang mempunyai laki-laki peliharaan). Maka disyariatkan laki-laki meminang untuk mengawini perempuan. Oleh karena itu, diantara ulama syalaf ada yang berpendapat bahwa perempuan itu tidak bisa menikahkan dirinya dan sesungguhnya perempuan pelacur itu ialah yang menikahkan dirinya. ${ }^{11}$

Pernikahan siri menurut hukum positif yang berlaku di Indonesia, suatu pernikahan yang diakui dan mendapat legalitas dari negara apabila memenuhi dan syarat sebagai berikut :

1. Telah memenuhi ketentuan hukum materiil, sebagaimana perintah undangundang No 1 tahun 1974 tentang pernikahan pasal 2 ayat 1 yaitu, pernikahan telah dilangsungkan menurut aturan yang di tentukan oleh hukum agama masing-masing, maka bagi orang Islam pernikahan itu sah apabila telah memenuhi syarat-syarat dan rukun yang telah ditetapkan oleh syariat Islam.

2. Telah memenuhi ketentuan hukum formiil, sebagaimana yang di kehendaki undang-undang pernikahan pasal 2 ayat 2 yaitu, pernikahan tersebut telah dicatatkan oleh pegawai pencatat nikah (PPN) yang berwenang dan telah memperoleh bukti autentik berupa Akte nikah.

Sedangkan dalam KHI Pasal 4 menyebutkan bahwa "Pernikahan adalah sah, apabila dilakukan menurut hukum Islam sesuai dengan pasal 2 ayat (1)Undang-undang No. 1 Tahun 1974 tentang Pernikahan". ${ }^{12}$ Nikah siri merupakan nikah yang telah memenuhi ketentuan syariat Islam dan dilakukan secara diam atau rahasia dari orang lain, termasuk dari pegawai pencatat nikah (PPN) sehingga tidak dicatatkan . dari sini dapat di pahami bahwa pernikahan siri baru memperoleh legalitas dari hukum Islam karna hanya syarat materiil saja yang dipenuhi, sedangkan syarat formil belum terpenuhi. ${ }^{13}$

Dalam penelitian ini memfokuskan pada dua rumusan masalah yang menjadi tolak ukur dalam penelitian ini, yaitu apa saja faktor yang melatarbelakangi terjadinya nikah siri? Dan bagaimana kedudukan hukum nikah siri dalam perspektif hukum Islam dan

\footnotetext{
10 Syaikh Al-allamah Muhammad bin Abdurrahman Ad-dimasyiqi, Fiqih Empat Mazhab, (Bandung: Hasyimi, 2015).hlm. 319

${ }^{11}$ Ibn Thamiyah,Hukum Hukum Perkawinan. Penerjemah:Risnan Yahya,(ed), Amir Hamzah, cet. ke-1 (Jakarta :Pustaka Al-khautzhar, 1997), hlm. 202 - 203.

12 Tim Redaksi Nansa Aulia, Kompilasi Hukum Islam, (Bandung: Nuansa Aulia, 2011), hlm. 2.

${ }^{13}$ Soedjono Dirojosworo ,Pengantar Ilmu Hukum, cet. ke-4 (Jakarta: Raja Gravindo Persada, 1994), hlm. 126.
} 
hukum positif?. Dari adanya rumusan tersebut bertujuan untuk menganalisis suatu faktor yang menjadi latar belakang terjadinya nikah siri dan untuk menjelaskan dalam bentuk diskripsi tentang kedudukan nikah siri dalam perspektif hukum Islam dan hukum positif.

\section{B. METODE PENELITIAN}

Metode adalah sebuah tata cara yang ditempuh oleh peneliti dalam melakukan sebuah penelitian. Dalam penelitian ini menggunakan jenis penelitian kualitatif yang berfokus pada data yang dikumpulkan yaitu data kepustakaan (library research). ${ }^{14}$ Sedangkan dalam pendekatan yang dilakukan dalam penelitian ini adalah sebuah pendekatan normatif dan komparatif. ${ }^{15}$ Serta beberapa data yang bersifat primer dan sekunder, yang meliputi sejumlah keterangan-keterangan dan fakta langsung yang diperoleh dari lapangan melalui sebuah wawancara dengan pihak-pihak yang dipandang mengetahui akan suatu hal diteliti dan dari fiqih empat madzhab, peraturan perundangundangan yang berlaku, dan kompilasi hukum Islam. Tehnik pengumpulan data dalam penelitian ini yaitu dengan studi dokumentasi, ${ }^{16}$ wawancara. ${ }^{17}$ Sedangkan analisis dalam penelitian ini menggunakan tehnik deskriptif analisis yaitu dengan metode analisis isi (content analisis) yang selalu memperhatikan konteksnya ${ }^{18}$

\section{PEMBAHASAN}

\section{Tinjauan Umum tentang Pernikahan Siri}

\section{a. Nikah Siri}

Secara literal Nikah Siri berasal dari bahasa Arab "nikah" yang menurut bahasa artinya mengumpulkan, saling memasukkan, dan digunakan untuk arti bersetubuh (wathi). Kata "nikah" sering dipergunakan untuk arti persetubuhan (coitus), juga untuk arti akad nikah.Sedangkan kata Siri berasal dari bahasa Arab "Sirr” yang berarti rahasia. Dengan demikian beranjak dari arti etimologis, nikah siri dapat diartikan sebagai pernikahan yang rahasia atau dirahasiakan. Dikatakan sebagai pernikahan yang dirahasiakan karena prosesi pernikahan semacam ini sengaja disembunyikan dari publik dengan berbagai alasan, dan biasanya dihadiri hanya oleh kalangan terbatas keluarga dekat, tidak dipestakan dalam bentuk resepsi walimatul ursy secara terbuka untuk umum.

\footnotetext{
${ }^{14}$ Sutrisno Hadi, Metodologi Research, (Yogyakarta: Andi Offect, 1989), hlm. 9.

${ }^{15}$ Soerjano Soekarto, Penelitian Hukum Normatif Suatu Tnjauan Singkat, cet. ke-11 (Jakarta: PT Raja Grafindo Persada, 2009), hlm. 13 - 14.

${ }^{16}$ Suharsimi Arikunto, Prosedur Penelitian, (Jakarta: Renika Cipta, 1996), hlm. 234.

${ }^{17}$ Moh. Nazir, Metode Penelitian, (Jakarta: Ghalia Indonesia, 1999), hlm. 63.

18 Winanmo Surahmad, Pengantar Penelitian Ilmu Dasar, (Bandung: Tarsito, 1985), hlm. $139-140$.
} 
Apabila kita berpedoman dari pengertian etimologis nikah siri sebagaimana tersebut di atas, maka setidaknya ada 3 (tiga) bentuk atau model nikah siri yang dilakukan dalam masyakat, yaitu:

1) Pernikahan antara seorang pria dengan seorang wanita yang sudah cukup umur yang dilangsungkan di hadapan dan dicatat oleh Pegawai Pencatat Nikah namun hanya dihadiri oleh kalangan terbatas keluarga dekat, tidak diumumkan dalam suatu resepsi walimatul ursy. Pernikahan model ini sengaja dilakukan secara diam-diam (siri) dengan alasan misalnya calon suami isteri tersebut dua-duanya mendapat tugas belajar S2 ke luar negeri secara mendadak, sehingga untuk menjaga kehalalan hubungan mereka selama menjalani studi mereka segera dinikahkan secara sederhana di hadapan PPN.

2) Pernikahan antara seorang pria dan seorang wanita yang masih di bawah umur menurut undang-undang, kedua-duanya masih bersekolah. Pernikahan ini atas inisiatif dari orang tua kedua belah pihak yang sepakat menjodohkan anak-anak mereka dengan tujuan untuk lebih memastikan perjodohan dan menjalin persaudaraan yang lebih akrab. Biasanya setelah akad nikah mereka belum kumpul serumah dulu. Setelah mereka tamat sekolah dan telah mencapai umur perkawinan, lalu mereka dinikahkan lagi secara resmi di hadapan PPN yang menurut istilah Jawa disebut "munggah". Pernikahan semacam ini pernah terjadi di sebagian daerah di Jawa Tengah pada tahun 1970an ke bawah.

3) Model pernikahan antara seorang pria dan seorang wanita yang sudah cukup umur menurut undang-undang akan tetapi mereka sengaja melaksanakan pernikahan siri, tidak dicatatkan di KUA dengan berbagai alasan. Pernikahan ini mungkin terjadi dengan alasan menghemat biaya, yang penting sudah dilakukan menurut tatacara agama sehingga tidak perlu dicatatkan di KUA. Atau mungkin, walaupun orang kaya akan tetapi tidak mau repot dengan berbagai macam urusan administrasi dan birokrasi sehingga lebih memilih nikah siri saja. Pernikahan semacam ini juga mungkin terjadi, misalnya dalam beberapa kasus kawin poligami liar, pernikahan dilaksanakan tidak di hadapan dan dicatat oleh PPN karena tanpa sepengetahuan isteri pertama. 
Pernikahan siri adalah pernikahan yang dilaksanakan dengan tidak memenuhi syarat dan peraturan perundang-undangan. Terdapat perbedaan tentang sah tidaknya pernikahan siri dikarenakan adanya perbedaan penafsiran terhadap ketentuan pasal 2 ayat (2) uu no 1 tahun 1974 tentang pernikahan. Yang jelas ketentuan pasal 2 ayat (2) yang mengharuskan pencatatan pernikahan terpisah dengan ketentuan pasal 2 ayat (1) yang mengatur tentang sahnya pernikahan yang harus dilakukan menurut hukum agama dan kepercayaan.

Menurut hukum Islam, pernikahan siri adalah sah, asalkan telah terpenuhi syarat rukun pernikahan. Namun dari aspek peraturan perundang-undangan pernikahan model ini belum lengkap dikarenakan belum dicatatkan. Pencatatan pernikahan hanya merupakan perbuatan administratif yang tidak berpengaruh pada sah tidaknya pernikahan.yang biasanya menjadi korban akibat adanya pernikahan model ini, yang dalam bentuk pengingkaran terjadinya pernikahan siri yang dilakukan, dan tak jarang pula anak yang dilahirkan dalam pernikahan itu juga tidak diakui . terkadang muncul permasalahan juga dalam hal pembagian waris.

Pasal 42 dan 43 UUP mengatur bahwa anak sah ialah anak yang dilahirkan dalam pernikahan yang sah, sedangkan anak yang dilahirkan dari pernikahan yang tidak sah hanya mempunyai hubungan hukum dengan ibunya. Dalam undang-undang pemerintah bahwa anak yang sah adalah anak yang lahir dari pasangan suami istri yang menikah sesuai dengan agama dan hukum pemerintah, sedangkan anak yang tidak sah adalah anak yang dilahirkan dari pasangan suami istri yang menikah sesuai agama saja, seperti pernikahan siri. Karena menurut hukum Islam, penikahan siri itu sah, maka anak yang dilahirkan dari pernikahan itu adalah sah.

Terjadinya nikah siri di masyarakat karena ada berbagai macam hal baik positif ataupun negatif seperti istri yang tidak dapat memberikan keturunan atau karena mahalnya biaya pernikahan ataupun kurangnya pendidikan dan ajaran agama.

Selain itu, ada beberapa Fenomena pernikahan nikah siri bagi umat Islam di Indonesia masih terbilang banyak. Bukan saja dilakukan oleh kalangan masyarakat bawah, tapi juga oleh lapisan masyarakat menengah keatas. Kondisi demikian terjadi karena beberapa faktor yang melatarbelakanginya. Tentu saja untuk mengetahui berapa besar persentase pelaku nikah siri dan faktor apa saja yang menjadi pemicu terjadinya pernikahan siri tersebut masih memerlukan penelitian yang seksama. Akan tetapi secara umum nikah siri dapat disebabkan oleh beberapa faktor, yaitu: kurangnya kesadaran 
hukum masyarakat, sikap apatis sebagian masyarakat terhadap hukum, ketentuan pencatatan pernikahan yang tidak tegas, dan ketatnya izin poligami. ${ }^{19}$

Pernikahan siri sering kali menimbulkan dampak negatif atau muadharat terhadap istri dan anak yang dilahirkan, terkait dengan hak-hak mereka seperti nafkah, atau hak waris. ${ }^{20}$ Seacara umum nikah siri diperbolehkan dalam kedudukan hukum Islam akan tetapi berbeda dengan kedudukan hukum nikah siri dalam hukum positif dari sudut pandang hukum yang berlaku di Indonesia, nikah siri merupakan pernikahan yang dilakukan tidak sesuai dengan ketentuan peraturan perundang-undangan yang berlaku. Sebagaimana kita pahami bahwa berdasarkan ketentuan Pasal 2 ayat (1) dan (2) UU No.1/1974 Jo. Pasal 4 dan Pasal 5 ayat (1) dan (2) KHI, suatu pernikahan di samping harus dilakukan secara sah menurut hukum agama, juga harus dicatat oleh pejabat yang berwenang. Dengan demikian, dalam perspektif peraturan perundang-undangan, nikah siri adalah pernikahan illegal dan tidak sah. ${ }^{21}$

\section{b. Hubungan Nikah Siri dengan Pencatatan Pernikahan}

Pernikahan adalah suatu perintah agama kepada yang mampu untuk segera melaksanakannya.karena dalam pernikahan dapat mengurasi perbuatan maksiat dan memelihara diri dari zina. Karna pernikahan merupakan perbuatan hukum maka tentu saja menimbulkan akibat hukum. Yang terjadi antara seorang laki-laki dan perempuan haram berhubungan badan. Setelah pernikahan menjadi halal. dari dalam hubungan itu menghasilkan keturunan, melahirkan keluarga sedarah dan samenda. Dari hubungan badan itu timbul hak-hak dan kewajiban lain seperti nafkah,waris hibah,dan warisan. ${ }^{22}$

Al-Qur'an dan hadist tidak mengatur secara rinci mengenai pencatatan pernikahan, namun dirasakan oleh masyarakat pentingnya hal itu, sehingga diatur dalam undang-undang no 1 tahun 1974 dan kompilasi hukum Islam, pencatatan penikahan bertujuan untuk mewujudkan ketertiban pernikahan dalam masyarakat. Baik pernikahan berdasarkan hukum Islam ataupun masyarakat yang melakukan pernikahan tidak berdasarkan hukum Islam.pencatatan pernikahan merupakan upaya untuk menjaga kesucian (mitsaqan ghalizan) aspek hukum yang timbul dari hukum pernikahan.

\footnotetext{
${ }^{19}$ Abd.Rahman Gazaly, Fiqh Munakahat,(Jakarta: Kencana, 2006), hlm. 5.

20 Indonesia, rancangan undang-undang hukum materiil peradilan agama bidang perkawinan, pasal 1

21 Soetojo Prawirohamidjojo, Pluralisme Dalam Perundang-undangan Perkawinan di Indonesia, (Surabaya: Airlangga University Press, 1994), hlm. 10.

${ }^{22}$ Yayan sopyan, Islam Negara Transformasi Hukum Perkawinan Islam Dalam Hukum Nasional (Jakarta :PT.Semesta Rakyat Merdeka,2010) Hlm.127
} 
Sebagai akibat adanya pemahan fiqih imam syafi'i yang sudah menbudaya dikalangan umat Islam indonesia. menurut paham mereka pernikahan telah dianggap cukup bila syarat dan rukunnya sudah terpenuhi,tanpa diikuti pencatatan,apalagi akta nikah.kondisi seperti ini terjadi dama masyarakat sehingga masih ditemukan pernikahan siri atau pernikahan dibawah tangan.kenyataan dalam masyarakat seperti ini merupakan hambatan undang-undang pernikahan.pasal 5 dan 6 Kompilasi Hukum Islam mengenai pencatatan pernikahan mengungkapkan beberapa garis hukum sebagai berikut. ${ }^{23}$

1) Agar terjamin ketertiban pernikahan bagi masyarakat Islam setiap pernikahan harus dicatat.

2) Pencatatan pernikahan, pada ayat 1 dilakukan oleh PPN sebagaiman di atur dalam Undang-Undang 22 tahun 46 jo Undang-Undang 32 tahun 1954.

3) Untuk memenuhi ketentuan pasal 5 setiap pernikahan harus dilangsungkan dihadapan dan dibawah pengawasan PPN.

4) Pernikahan yang dilakukan diluar pengawasan PPN yang tidak mempuyai kekuatan hukum. ${ }^{24}$

\section{c. Dampak Pernikahan Siri Bagi Perempuan}

Meski secara agama atau adat istiadat dianggap sah, namun pernikahan yang dilakukan tanpa sepengatahuan dan pengawasan pegawai pencatat nikah tidak memiliki kekuatan hukum dan di anggap tidak sah dimata hukum. Dampak dari pernikahan siri bagi perempuan sebagai berikut:

1) Secara Hukum

a) Istri siri tidak dianggap sebagai istri sah.

b) Istri siri tidak berhak atas nafkah dan warisandari suami jika ia meninggal dunia.

c) Istri siri tidak berhak atas harta gono-gini jika terjadi perpisahan, karena secara hukum pernikahan anda d ianggap tidak pernah terjadi.

d) Istri siri tidak bisa memperoleh perlindungan hukum bila terjadi kekerasan dalam rumah tangga.

e) Semua dampak hukum yang menjadi beban istri diatas juga berlaku pada anak yang dilahirkan atas pernikahan siri.

2) Secara Sosial

${ }^{23}$ Zainuddin Ali, Hukum Perdata Islam Indonesia, (Palu :Sinar Grafika, 2006), hlm. 26-27.

${ }^{24}$ Kompilasi Hukum Islam, Pasal 5 dan 6. 
a) Istri siri akan sulit bersosialisasi karena perempuan yang melakukan pernikahan siri sering dianggap telah tinggal serumah dengan laki-laki tanpa ikatan pernikahan (alias kumpul kebo) atau anda dianggap menjadi istri simpanan.

b) Istri yang seharusnya di lindungi, justru dirugikan dari berbagai aspek.

c) Beban sosial tersebut pastinya juga akan berpengaruh kepada jiwa anak.

\section{d. Dampak Nikah Siri Terhadap Anak}

Sementara terhadap anak, tidak sahnya pernikahansiri menurut hukum negara memiliki dampak negatif bagi status anak yang dilahirkan di mata hukum, yakni:

1) Status anak yang dilahirkan dianggap sebagai anak tidak sah. Konsekuensinya.

2) Anak hanya mempunyai hubungan perdata dengan ibu dan keluarga ibu. Artinya, si anak tidak mempunyai hubungan hukum terhadap ayahnya (pasal 42 dan pasal 43 UU Pernikahan, pasal $100 \mathrm{KHI})$. Di dalam akte kelahirannyapun statusnya dianggap sebagai anak luar nikah, sehingga hanya dicantumkan nama ibu yang melahirkannya. Keterangan berupa status sebagai anak luar nikah dan tidak tercantumnya nama si ayah akan berdampak sangat mendalam secara sosial dan psikologis bagi si anak dan ibunya.

3) Ketidakjelasan status si anak di muka hukum, mengakibatkan hubungan antara ayah dan anak tidak kuat, sehingga bisa saja, suatu waktu ayahnya menyangkal bahwa anak tersebut adalah anak kandungnya.

4) anak tidak berhak atas biaya kehidupan dan pendidikan, nafkah dan warisan dari ayahnya.

Namun hal diatas sudah tidak seharusnya menjadi ketakutan para ibu dan sianak tersebut disebabkan sudah ada Putusan Mahkamah Konstitusi Republik Indonesia Nomor 46/PUU-VIII/2010, Tanggal 13 Februari 2012. Putusan Mahkamah Konstitusi Nomor 46/PUU-VIII/2010 yang mengadili perkara konstitusi pada tingkat pertama dan terakhir, menjatuhkan putusan dalam perkara permohonan pengujian Undang-Undang Nomor 1 Tahun 1974 tentang Pernikahan terhadap Undang-Undang Dasar Negara Republik Indonesia Tahun 1945 Berdasarkan Pasal 51 ayat 1 UU 24/2003 untuk mengajukan perkara konstitusi si pemohon harus memiliki kedudukan hukum (legal standing), 
sebagai pihak yang menganggap hak dan/atau kewenangan konstitusionalnya dirugikan oleh berlakunya undang-undang, yaitu :

a) Perorangan warga Negara Indonesia.

b) Kesatuan masyarakat hukum adat sepanjang masih hidup dan sesuai dengan perkembangan masyarakat dan prinsip Negara Kesatuan Republik Indonesia yang diatur dalam undang-undang.

c) Badan hukum publik atau privat atau lembaga Negara.

Dengan demikian, dalam pengujian undang-undang terhadap UUD 1945 harus menjelaskan dan membuktikan terdahulu:

1) Kedudukannya sebagai para pemohon sebagaimana yang dimaksud dalam pasal 51 ayat 1 UU 24/2003 tentang kerugian hak/ kewenangan konstitusional yang diberikan oleh berlakunya undang-undang yang dimohonkan pengujian. Pemohon mengajukan uji materiil terhadap UUD 1945 dan UU no 1 tahun 1974 tentang pernikahan.

2) UUD 1945

a) Pasal 28 B ayat 1 "setiap orang berhak membentuk keluarga dan melanjutkan keturunan melalui pernikahan yang sah".

b) Pasal 28 B ayat 2 "setiap anak berhak atas kelangsungan hidup, tumbuh, dan berkembang serta berhak atas perlindungan dari kekerasan dan diskriminasi"

c) Pasal $28 \mathrm{D}$ ayat 1"setiap orang berhak atas pengakuannya, jaminan, perlindungan, dan kepastian hukum yang adil serta yang sama dihadapan hukum".

3) UU no 1 tahun 1974 tentang pernikahan

a) Pasal 2 ayat 2 "tiap-tiap pernikahan dicatat menurut peraturan perundangundangan yang berlaku".

b) Pasal 43 ayat 1 "anak yang dilahirkan diluar pernikahan hanya mempunyai hubungan perdata dengan ibunya dan keluarga ibunya.

Pada pengujian diatas mahkamah konstitusi memberikan putusan dimana telah mengabulkan sebagian .dimana pada pasal 2 ayat 2 UU pernikahan tidak dikabulkan disebabkan karena pernikahan diatas harus dicatatkan adalah untuk mencapai tertibnya administrasi tersebut. Sedangkan dalam pasal 43 ayat 1 UU pernikahan dikabulkan karena hubungan anak dengan seorang laki-laki sebagai bapak tidak semata-mata karena adanya 
ikatan pernikahan, akan tetapi dapat juga didasarkan pada pembuktian adanya hubungan darah antara anak dengan laki-laki tersebut seperti bapak. Dengan demikian, terlepas dari prosedur atau administrasi pernikahan, anak yang dilahirkan harus mendapat perlindungan hukum.

\section{Analisis atas faktor Penyebab Terjadinya Nikah Siri}

Dalam kehidupan bermasyarakat, pernikahan dan keluarga merupakan institusi yang sangat penting. Melalui pernikahan bisanya menimbulkan berbagai konsekuensi, karena itu diaturlah prosedur guna menghindari kemungkinan-kemungkinan negatif yang merugikan. Diantara prosedur dan aturan yang dibuat bagi masyarakat Islam di Indonesia adalah bahwa pernikahan harus dicatat secara resmi dan dipublikasikan. Pencatatan resmi biasanya dilakukan oleh Petugas Pencatat Nikah (PPN) atau Kantor Urusan Agama sebagai lembaga resmi pemerintah, sedangkan publikasi secara formal biasanya dilakukan dalam bentuk acara walimahan atas resepsi.

Namun kenyataannya, tidak semua masyarakat Islam di Indonesia mengikuti prosedur atau aturan yang berlaku. Pada sebagian masyarakat Islam di Indonesia berkembang terma dan praktek nikah yang tidak tercatat dan tidak dipublikasikan. Pernikahan semacam ini dinamakan nikah siri, dan juga ada sebagian masyarakat yang menyebutnya dengan nikah agama atau nikah siri. Nikah ini pada sebagian masyarakat masih terdapat keragaman pemahaman tentang terminologi dan konsep nikah siri. Hal ini dapat dipahami karena konsepnya belum tersosialisasi secara menyeluruh, sebagian ulama dan masyarakat umumnya belum memiliki kejelasan kesamaan rumusan. ${ }^{25}$

Realitas demikian itu sering menimbulkan perbedaan persepsi terhadap tindakan atau praktek nikah Siri. Secara normatif, ada masyarakat yang menilai praktek nikah siri dinyatakan sah dan dapat menimbulkan implikasi negatif. Karena itulah, untuk memahami persepsi masyarakat terhadap praktek nikah siri, maka terlebih dahulu perlu memahami persepsi mereka tentang konsep nikah sirinya. Sesuai dengan namanya, nikah siri merupakan pernikahan yang dilakukan secara terselubung, atau sembunyi-sembunyi. Praktek-praktek nikah siri ini banyak dikenal dan dilakukan oleh sebagian masyarakat di Indonesia. Sementara itu, jika dilihat dari perspektif hukum pemerintahan dan norma sosial, sering dinilai sebagai suatu deviasi atau penyimpangan.

25 Dadi Nurhadi, Nikah Di Bawah Tangan (Praktek Nikah Sirri Mahasiswa Jogja), (Yogyakarta: Saujana, 2003), hlm. 27. 
Adapun para pelaku nikah siri ini terdiri dari berbagai lapisan masyarakat, baik dilihat dari segi usia, status sosial, dan sebagainya. Diantara masyarakat itu, fenomena banyaknya praktek nikah siri terjadi pada sebagian masyarakat Desa Lemper kecamatan Pademawu Kabupaten Pamekasan, yang memiliki tingkat intelektualitas beragam, dan pengetahuan terhadap ketentuan hukum (pernikahan) juga beragam.

Dari hasil wawancara dengan responden (pelaku nikah siri di Desa Lemper Kecamatan Pademawu Kabupaten Pamekasan), dapat disimpulkan bahwa kebanyakan mereka memberikan pengertian bahwa secara legal formal (fikih) Islam dapat dinyatakan sah. Hal ini didasarkan pada alasan bahwa pada saat peresmian nikah siri semacam itu semua syarat dan rukun yang telah ditentukan telah terpenuhi. Semua rukun yang dimaksud itu ialah adanya mempelai laki-laki dan perempuan, wali (yang menikahkan), bagi sah tidaknya suatu pernikahan secara Islam. Sedangkan berkaitan dengan pencatatan di KUA dan adanya publikasi (yang biasanya dilaksanakan dalam bentuk walimah/resepsi), secara substansial keduanya lebih didasarkan untuk tujuan kemashlahatan. ${ }^{26}$

Hukum dapat dijadikan alat rekayasa social dalam rangka mewujudkan kemashlahatan umat manusia sebagai tujuan hakiki hukum itu sendiri. Berdasarkan penelitian terhadap 3 pasangan nikah siri yang diperoleh melalui wawancara, dapat penulis paparkan profil pasangan nikah yang ada di Desa Lemper sebagai berikut :

1) Profil Moh Tohir Efendi dan Ummi kulsum

Tohir (28 tahun) berasal dari Desa Lemper Pademawu, bujang yang berprofesi mahasiswa dan ummi kulsum (23 tahun), seorang gadis yang berasal dari Desa lemper pademawu. Keduanya masih sebagai pelajar/mahasiswa. Alasan mereka menikah siri yaitu beranggapan bahwa pernikahan akan merepotkan proses studi mereka. ${ }^{27}$

2) Profil Syamsuddin dan Misnatun

Syamsuddin (35 tahun) seorang duda berasal dari desa teja barat yang berprofesi sebagai pedagang,dan Misnatun (25tahun) single berasal dari lemper. Alasan mereka menikah siri yaitu untuk menghindarkan dari fitnah masyarakat,karena mereka sudah sering bersama. ${ }^{28}$

\footnotetext{
${ }^{26}$ Hasil wawancara dengan pasangan Nikah Sirri di Desa Lemper Pademawu Pamekasan pada tanggal 19 April 2016.

${ }^{27}$ Hasil wawancara Moh Tohir Efendi dan Ummi Kulsum pada tanggal 28 juni 2016

${ }^{28}$ Hasil wawancara Syamsuddin dan Misnatun pada tanggal 20 April 2016
} 
3) Profil Ali ridho dan Iis

Ali Ridho (28 tahun) berprofesi sebagai tukang yang berasal dari desa lemper pademawu, dan Iis (23 tahun) berasal dari desa lemper juga.Awalnya mereka kumpul kebo dan berkeinginan untuk menikah secara resmi, namun karena keadaan ekonomi mereka yang tidak mencukupi untuk biaya pernikahan secara resmi, akhirya mereka melakukan pernikahan siri. ${ }^{29}$

Dari uraian di atas dapat disimpulkan bahwa alasan melakukan nikah siri adalah sebagai berikut :

1) Mahalnya biaya perkawinan.

2) Kendala pada masa studi.

3) Kurangnya pendidikan dan pemahaman ajaran agama.

Adapun tujuan yang ingin dicapai oleh para pelaku nikah siri itu meliputi tujuan yang bersifat normatif, tujuan yang bersifat psikologis, tujuan yang bersifat biologis, dan tujuan yang bersifat sosial ekonomis. ${ }^{30}$ Sebagaimana yang diungkapkan Emile Durkheim bahwa fakta sosial dianggap sebagai barang sesuatu (thing) yang berbeda dengan ide yang menjadi obyek penyelidikan seluruh ilmu pengetahuan dan tidak dapat dipahami melalui kegiatan mental murni (spekulatif). Tetapi untuk memahaminya diperlukan penyusunan data riil diluar pemikiran manusia.

Fakta sosial yang dimaksud pada uraian di atas, terdiri atas dua jenis fakta sosial, yaitu :

1) Dalam bentuk material, berupa barang sesuatu yang dapat disimak, ditangkap dan diobservasi, contohnya arsitektur atau nama hukum.

2) Dalam bentuk non material, merupakan fenomena yang terkandung dalam diri manusia sendiri hanya muncul dalam kesadaran manusia. ${ }^{31}$

\section{Kedudukan Nikah Siri dalam Perspektif Hukum Islam dan Hukum}

\section{Positif.}

a. Kedudukan Nikah Siri Menurut Hukum Islam

Dalam ketentuan fatwa ijtima' ulama komisi fatwa se-indonesia II tahun 2006 disebutkan :

\footnotetext{
${ }^{29}$ Hasil wawancara Ali ridho dan Iis pada tanggal 21 April 2016

${ }^{30}$ Jalaluddin Rahmad, Psikologi Komunikasi, (Bandung: Rosdakarya, 1996), hlm. 18.

${ }^{31}$ Emile Durkhim, Sosiologi dan Filsafat, (Surabaya: Erlangga, 1991), hlm. 25.
} 
1) Pernikahan siri hukumnya sah karna telah terpenuhi syarat dan rukun nikah, tetapi haram ketika terdapat mudharat.

2) Pernikahan harus dicatatkan secara resmi pada instansi yang berwenang sebagai langkah presensif untuk menolak dampak negativ/ mudharat (saddan lidz-dhari'ah). ${ }^{32}$

Pernikahan siri sering menimbulkan dampak negative atau mudharat terhadap istri atau anak yang dilahirkan terkait dengan hak hak mereka seperti nafkah ataupun hak waris dan sebagainya. Tuntutan pemenuhan hak-hak tersebut sering kali menimbulkan sengketa. Namun demikian untuk menghindari kemudhoratan, peserta ijtima' ulama sepakat bahwa pernikahan harus dicatatkan secara resmi kepada instansi yang berwenang.

b. Kedudukan Nikah Siri Menurut Hukum Positif

Dari sudut pandang hukum yang berlaku di Indonesia, nikah siri merupakan perkawinan yang dilakukan tidak sesuai dengan ketentuan peraturan perundang-undangan yang berlaku. Sebagaimana kita pahami bahwa berdasarkan ketentuan Pasal 2 ayat (1) dan (2) UU No.1/1974 Jo. Pasal 4 dan Pasal 5 ayat (1) dan (2) KHI, suatu perkawinan di samping harus dilakukan secara sah menurut hukum agama, juga harus dicatat oleh pejabat yang berwenang. Dengan demikian, dalam perspektif peraturan perundangundangan, nikah siri adalah pernikahan illegal dan tidak sah.

Bagi kalangan umat Islam Indonesia, ada dua persyaratan pokok yang harus dikondisikan sebagai syarat kumulatif yang menjadikan perkawinan mereka sah menurut hukum positif, yaitu: pertama, perkawinan harus dilakukan menurut hukum Islam, dan kedua, setiap perkawinan harus dicatat. Pencatatan perkawinan tersebut dilakukan oleh PPN sesuai UU No.22/1946 jo. UU No.32/1954. Dengan demikian, tidak terpenuhinya salah satu dari ketentuan dalam pasal 2 tersebut menyebabkan perkawinan batal atau setidaknya cacat hukum dan dapat dibatalkan.

Akan tetapi kalau ketentuan pasal tersebut masih dipahami sebagai syarat alternative, maka perkawinan dianggap sah meskipun hanya dilakukan menurut hukum agama dan tidak dicatatkan di KUA. Permasalahan hukum

\footnotetext{
${ }^{32}$ Asrorun Ni'am Sholeh, Fatwa-Fatwa Masalah Pernikahan Dan Keluarga, (Jakarta :elSAS, 2008), hlm. 49.
} 
mengenai sah atau tidaknya suatu perkawinan yang tidak dicatatkan akan selalu menjadi polemic berkepanjangan bila ketentuan undang-undangnya sendiri tidak mengaturnya secara tegas. Dalam arti kewajiban pencatatan tersebut harus dinyatakan secara tegas dan disertai sanksi bagi yang melanggarnya.

Bagi umat Islam, kepentingan pencatatan itu sendiri sebenarnya mempunyai dasar hukum Islam yang kuat mengingat perkawinan adalah suatu ikatan perjanjian luhur dan merupakan perbuatan hukum tingkat tinggi. Artinya, Islam memandang perkawinan itu lebih dari sekedar ikatan perjanjian biasa. Dalam Islam, perkawinan itu merupakan perjanjian yang sangat kuat (mitsaqan ghalidhan). Bagaimana mungkin sebuah ikatan yang sangat kuat dipandang enteng? Mengapa logika sebagian umat Islam terhadap wajibnya pencatatan perkawinan seperti mengalami distorsi? Perlu kita yakinkan kepada umat Islam bahwa pencatatan perkawinan hukumnya wajib syar'i. Sungguh sangat keliru apabila perkawinan bagi umat Islam tidak dicatatkan sesuai dengan ketentuan hukum yang berlaku. Sedangkan ikatan perjanjian biasa, misalnya semacam utang piutang di lembaga perbankan atau jual beli tanah misalnya saja perlu dicatat, mengapa ikatan perkawinan yang merupakan perjanjian luhur dibiarkan berlangsung begitu saja tanpa adanya pencatatan oleh pejabat yang berwenang. Adalah ironi bagi umat Islam yang ajaran agamanya mengedepankan ketertiban dan keteraturan tapi mereka mengebaikannya.

\section{SIMPULAN}

Dalam penelitian ini dapat diambil kesimpulan bahwa pernikahan siri atau pernikahan tanpa pencatatan baik nikah tunggal maupun karena poligami adalah pernikahan yang tidak sah dihadapan hukum positif. Hal ini terjadi disebabkan karena kurangnya pemahaman hukum dan minimnya kesadaran hukum dari sebagian masyarakat akan pentingnya pencatatan perkawinan mereka. Selain itu kesimpulan yang kami dapat dari faktor yang melatarbelakangi terjadinya pernikahan siri itu sendiri adalah mahalnya biaya perkawinan, kendala pada masa studi, dan kurangnya pendidikan dan pemahaman ajaran agama. Selanjutnya 
TAHKIM, Jurnal Peradaban dan Hukum Islam. Vol.4 No.l (Maret, 202I) | ISSN : 2597-7962

adalah sebuah kedudukan nikah siri menurut hukum Islam hukumnya sah karna telah terpenuhi syarat dan rukun nikah, tetapi haram ketika terdapat mudharat.

Adapun dari sudut pandang hukum yang berlaku di Indonesia, nikah siri merupakan perkawinan yang dilakukan tidak sesuai dengan ketentuan peraturan perundang-undangan yang berlaku. Sebagaimana kita pahami bahwa berdasarkan ketentuan Pasal 2 ayat (1) dan (2) UU No.1/1974 Jo. Pasal 4 dan Pasal 5 ayat (1) dan (2) KHI, suatu perkawinan di samping harus dilakukan secara sah menurut hukum agama, juga harus dicatat oleh pejabat yang berwenang. Dengan demikian, dalam perspektif peraturan perundang-undangan, nikah siri adalah pernikahan illegal dan tidak sah. 
TAHKIM, Jurnal Peradaban dan Hukum Islam. Vol.4 No.l (Maret, 202I) | ISSN : 2597-7962

\section{DAFTAR PUSTAKA}

Ali, Zainuddin. (2006). Hukum Perdata Islam Indonesia, Palu :Sinar Grafika.

Arikunto, Suharsimi. (1996). Prosedur Penelitian, Jakarta: Renika Cipta.

Dirojosworo, Soedjono. (1994). Pengantar Ilmu Hukum, cet. ke-4, Jakarta: Raja Gravindo Persada.

Durkhim, Emile. (1991). Sosiologi dan Filsafat, Surabaya: Erlangga.

Gazaly, Rahman. (2006). Fiqh Munakahat, Jakarta: Kencana.

Hadi, Sutrisno. (1989). Metodologi Research, Yogyakarta: Andi Offect.

Ibn Thamiyah. (1997). Hukum Hukum Perkawinan. Penerjemah:Risnan Yahya,(ed), Amir Hamzah, cet. ke-1, Jakarta :Pustaka Al-khautzhar.

Indonesia, rancangan undang-undang hukum materiil peradilan agama bidang perkawinan, pasal 1

Jalil, Abdul (ed). (2000). Fiqh Rakyat: Pertautan Fiqh dengan Kekuasaan, Yogyakarta: LKiS.

Kompilasi Hukum Isalm, Pasal 5 dan 6.

Nazir, M. (1999). Metode Penelitian, Jakarta: Ghalia Indonesia.

Nuradi, Dadi. (2003). Nikah Di Bawah Tangan (Praktek Nikah Siri Mahasiswa Jogja), Yogyakarta: Saujana.

Prawirohamidjojo, Soetojo. (1994). Pluralisme Dalam Perundang-undangan Perkawinan di Indonesia, Surabaya: Airlangga University Press.

Rahmad, Jalaluddin. (1996). Psikologi Komunikasi, Bandung: Rosdakarya.

Rasyid, Sulaiman. (1992). Fiqh Islam, cet. ke-25, Bandung: CV Sinar Baru.

Rofiq, Ahmad. (1998). Hukum Islam di Indonesia, cet. ke-3, Jakarta: Raja Grafindo Persada.

Sholeh, Asrorun Ni'am. (2008). Fatwa-Fatwa Masalah Pernikahan Dan Keluarga, Jakarta :elSAS.

Soekarto, Soerjano. 2009). Penelitian Hukum Normatif Suatu Tnjauan Singkat, cet. ke-11, Jakarta: PT Raja Grafindo Persada.

Sopyan, Yayan. (2010). Islam Negara Transformasi Hukum Perkawinan Islam Dalam Hukum Nasional, Jakarta :PT.Semesta Rakyat Merdeka.

Surahmad, Winanmo. (1985). Pengantar Penelitian Ilmu Dasar, Bandung: Tarsito.

Syaikh Al-allamah, M. A. (2015). Fiqih Empat Mazhab, Bandung: Hasyimi.

Tim Redaksi Nansa Aulia. (2011). Kompilasi Hukum Islam, Bandung: Nuansa Aulia.

Zuhdi, Masjfuk. (1996). "Nikah Siri, dan Status Anaknya menurut Hukum Islam dan Hukum Positif”, dalam Mimbar Hukum, VII, 28. 